\title{
Effect of basidiomycete fungi on the discoloration and phytotoxicity of synthetic dye and textile effluent
}

\author{
Ana Paula Acerbi Ribeiro ${ }^{1}$, Ligiane Aparecida Florentino ${ }^{2}$, Sára Maria Chalfoun ${ }^{3}$ \\ ${ }^{1}$ M.Sc. Universidade Federal de Lavras, Brazil \\ ${ }^{2}$ Professor, PhD - Universidade José do Rosário Vellano, Brazil \\ ${ }^{3}$ Researcher, PhD - EPAMIG Sul, Brazil
}

\begin{abstract}
The elimination of toxic wastes from industrial activities, mainly the textile industry, has induced the researchers to seek new techniques that reduce or eliminate the toxicity of these effluents. The textile effluent has a high chemical demand of oxygen and strong coloration, requiring an especific treatment. The aim of this study was to evaluated the decolorizationRemazol Brilliant Blue $R(R B B R)$ and textile effluent using pre-selected cultures of basidiomycete fungi: Lentinula edodes, Pleurotusostreatus and Pleutotuspulmorarius, and phytotoxicity of the dye and effluent before and after treatment with fungi. The decolorization test was realized in a liquid medium and the absorbance determined in spectrophotometer. For the dye was used to two $\mathrm{pH}$ values (5.0 and 9.0) and concentration (0.1 gL-1 and $0.5 \mathrm{gL}-1)$. Lactuca sativa L. seeds were exposed to dye samples and textile effluents and the parameters evaluated were the germination rate and root lenght. The fungus Pleurotuspulmonarius was the one with the best result on the decolorization of dye RBBR on the both values: $\mathrm{pH}$ and concentration. As the textile effluent there was no significant difference among the treatments. In some treatments with the dye germination rate decreased indicating toxicity after decolorization. However there was an increase in root growth in the presence of the dye treated with P.pulmonarius.
\end{abstract}

Keywords-Pleurotuspulmonarius; Remazol Brilliant Blue R.; Decolorization; Toxicity.

\section{INTRODUCTION}

In recent years, studies on urban environmental problems have been gaining prominence, mainly because the evolution of urban centers and continued population growth have led to the emergence of some forms of pollution that have reached catastrophic dimensions, which can be observed through changes quality of soil, air and water [1].

The textile sector is one of the activities that contribute most to the environmental contamination, because it uses in its processes large volumes of water, besides several substances during the staining, such as caustic soda, gums, detergents, defoamers, chlorine, formols, emulsions, oils and resins, among others. This leads to the production of a complex, toxic and recalcitrant residue [2].

Approximately 8,000 different dyes and pigments are used industrially, representing an annual consumption of around 800 000 tonnes worldwide, of which approximately $10-15 \%$ is discharged into the environment [3].

The textile effluent has high chemical oxygen demand and coloration due to the presence of dyes, pigments and auxiliary chemicals, which causes that the effluent needs a specific treatment [4].

When not properly treated and released into water bodies, the effluents from the textile fiber dyeing process can modify the ecosystem, reducing the transparency of the water and the penetration of solar radiation, which can modify the photosynthetic activity and the solubility regime of gases [5].

With regard to the removal of textile dyes present in industrial effluents, new technologies have been sought to minimize the environmental damages they may cause. Although there are physical and chemical forms of treatment of textile effluents, microorganisms have been intensively studied for this purpose [6].

Studies indicate that lignin-degrading basidiomycete fungi are efficient in the degradation of several compounds, including dyes, presenting high action potential in the recovery of contaminated environments [7].

The extracellular enzymes present in these fungi (lignin peroxidase, manganese peroxidase and laccase) are an effective means of degradation of pollutants, presenting specific mechanisms of degradation of recalcitrant compounds. However, there is a demand for biological agents not only able to degrade these effluents more efficiently, but also to reduce their toxicity [8]. 
It is in this context, from the constant search for alternative methods of treatment of effluents, that the need arises to study new fungal species that have degradation capacity of dyes and textile effluents, aiming at the optimization of traditional treatment processes.

The present work was carried out with the objective of evaluating the discoloration of Remazol Brilliant Blue R dye and textile effluent using pre-selected basidiomycete fungi cultures and verify the phytotoxicity of the dye and effluent before and after treatment with fungi, with Lactuca sativa $\mathrm{L}$.

\section{MATERIAL AND METHODS}

The dye used was the Remazol Brilliant Blue $\mathrm{R}$,Sigma - Aldrich $^{\circledR}$, being an anthraquinone type dye. Its empirical formula is $\mathrm{C} 22 \mathrm{H} 16 \mathrm{~N} 2 \mathrm{Na} 2 \mathrm{O} 11 \mathrm{~S} 3$ and its molecular weight, $626.54 \mathrm{~g} / \mathrm{mol}$.

The effluent was collected from the receiving tank of the effluent treatment plant (ETE) of the TrelConfecções Ltda. Textile industry, located in the city of Lavras, MG. The industry manufactures garments, and RBBR (Remazol Brilliant Blue R) textile dye is routinely used.

The sample was collected in previously sterilized flasks, totaling $1,000 \mathrm{~mL}$, which were then taken to the Laboratory of Microbiology of the Agricultural Research Institute of Minas Gerais (EPAMIG), located at the Federal University of Lavras Campus in Lavras, MG. .

For the discoloration treatments with the RBBR textile dye and the textile effluent, basidiomycete fungi Lentinula edodes (INCQS - FIOCRUZ 40220), Pleurotusostreatus and Pleurotuspulmonarius were used. The first one was donated by the Oswaldo Cruz Foundation of Rio de Janeiro and the others by the Laboratory of Edible Mushrooms of the Federal University of Lavras.

The basidiomycetes fungi used were initially inoculated into Petri dishes with AM medium. After seven days of incubation at $25^{\circ} \mathrm{C}$, three $5 \mathrm{~mm}$ diameter disks containing the fungal samples were removed from the colonies of each fungus under study and transferred to $250 \mathrm{~mL}$ Erlenmeyers containing $50 \mathrm{~mL}$ of malt extract (EM) $2 \%$ supplemented with the RBBR dye [7].

Two concentrations of the dye (0.1 and $0.5 \mathrm{~g} \mathrm{~L}-1)$ and two $\mathrm{pH}$ values (5.0 and 9.0) were used. These values of $\mathrm{pH}$ and dye concentration were analyzed, since they are the most found in the treatment tanks of the effluent treatment plants (ETE) of the textile industries.

The flasks were incubated at $28^{\circ} \mathrm{C}$ (mean treatment tank temperature) in the dark and under agitation of $150 \mathrm{rpm}$. After 15 days, aliquots of $5 \mathrm{ml}$ of the supernatant were filtered in $0.45 \mu \mathrm{m}$ membrane (Whatman PVDF) for spectrophotometric analysis (BEL PHOTONICS - SP 1105). The wavelength in which the dye had the highest absorbance was used. Each test presented as a control flasks containing $2 \%$ culture medium and dye, without the fungal sample. When necessary, dilutions of the samples were made. A standard curve was drawn from the initial solution $(0.5 \mathrm{~g} \mathrm{~L}-1$ of RBBR $)$ and different dilutions in $2 \% \mathrm{MS}$ with their respective absorbance at the same wavelength used to monitor the behavior of the dye.

Disks containing the fungi samples were transferred to flasks containing $50 \mathrm{~mL}$ of the untreated textile effluent, supplemented with $0.5 \%$ MS. The same wavelength used for the RBBR dye was used and, as a control, flasks only with the textile effluent, without the fungal sample.

Seeds of the same batch of lettuce (Lactuca sativa L.) cv. Summer Wonder (Topseed), purchased locally. The evaluated parameters were germination rate (TG) and root length (CR). The biological tests were performed according to Rodríguez et al. (2006), with modifications. The bioassays were conducted at room temperature for seven days, when observations and calculations of germination rate and root length were performed.

All experiments were performed in triplicate, both for the samples and for the controls. Data from all discoloration and phytotoxicity tests were submitted to analysis of variance (ANOVA) and the means were compared by the Scott-Knott test at $5 \%$ significance.

\section{RESULTS AND DISCUSSION}

The discoloration capacity of RBBR dye and textile effluent was tested by the three fungi cultures, Lentinula edodes, Pleurotusostreatus and Pleurotuspulmonarius. The results, after 15 days of treatment with the RBBR dye in the different values of $\mathrm{pH}$ and concentration and with the textile effluent, can be seen in Figs. 1I, 1II and 1III. 
Lentinula edodes showed better discoloration in the treatment with RBBR dye at $\mathrm{pH} 5.0$ and 0.5 gL-1 (Fig.1I) and Pleurotusostreatus fungus, in treatments at $\mathrm{pH} 5.0$ and $0.5 \mathrm{gL}-1$ and in $\mathrm{pH} 9.0$ and $0.5 \mathrm{gL}-1$ (Fig.1 II). However, the fungus Pleurotuspulmonarius showed a significant difference for all treatments with the dye (Fig.1III ). Regarding the treatments with the textile effluent, there was no significant difference for any of the fungi tested.
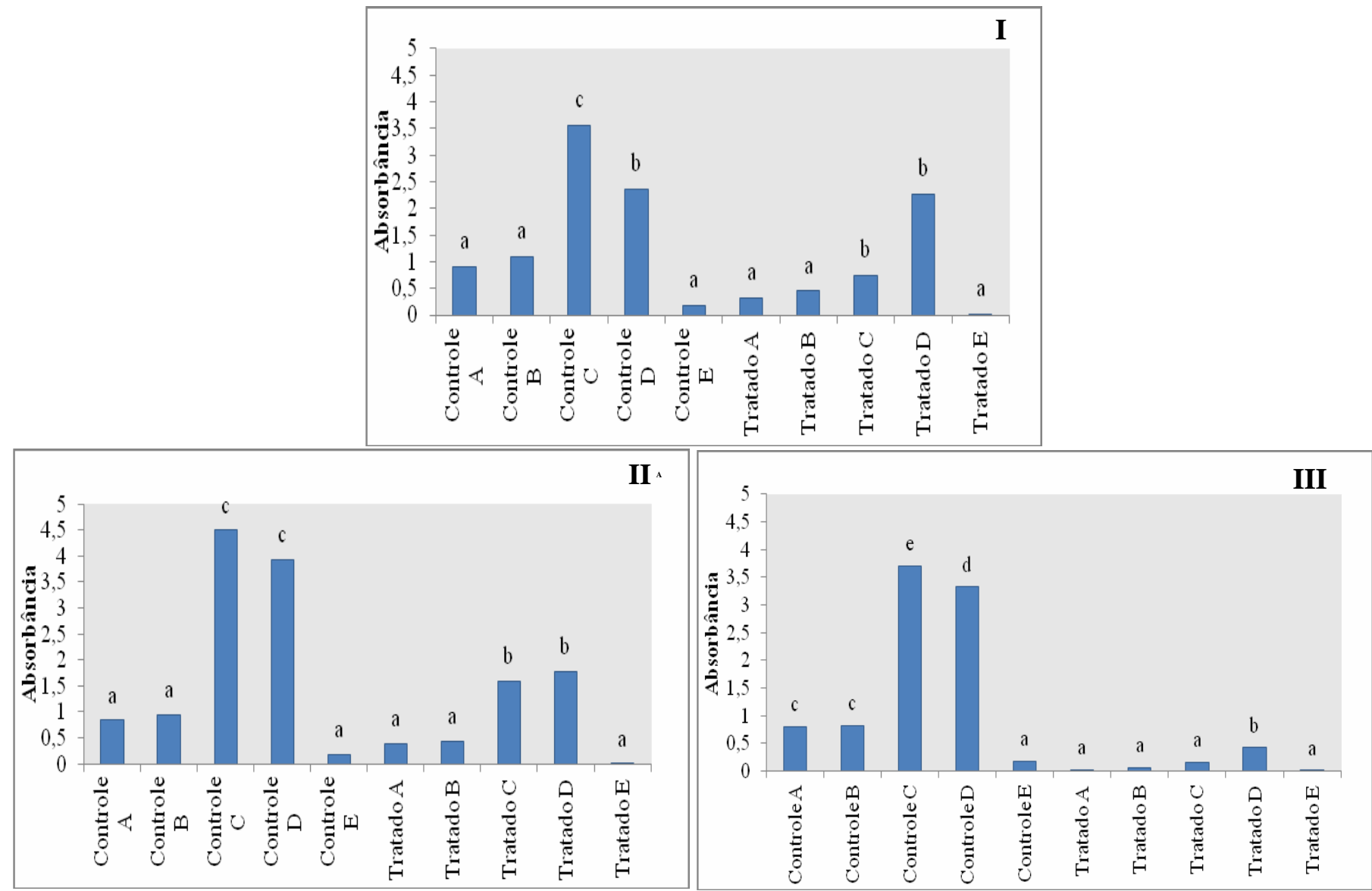

FIG. 1: Treatment with the fungi Lentinula edodes (I), Pleurotusostreatus (II) and Pleurotuspulmonarius (III). (A) RBBR dye at pH 5.0 and $0.1 \mathrm{gL}-1$; (B) RBBR dye at pH 9.0 and $0.1 \mathrm{gL}-1$; (C) RBBR dye at pH 5.0 and $0.5 \mathrm{gL}-1$; (D) RBBR dye at pH 9.0 and $0.5 \mathrm{gL}-1$; (E) textile effluent. In controls there was no presence of inoculum. CV $=\mathbf{5 6 . 4 5 \%}$. Means followed by the same letter do not differ by Scott-Knott test at $5 \%$ significance.

Some treatments using pH 9.0 were efficient in dye discoloration, however, most discolored better at $\mathrm{pH}$ 5.0. [9] also performed discoloration experiments of the RBBR dye in order to evaluate the most appropriate $\mathrm{pH}$. They used a $\mathrm{pH}$ range between 3.0 and 7.0, with the best discoloration results being those at $\mathrm{pH}$ in the range of 4.0 and 5.0.

The discoloration activity of the RBBR dye is an indicative method of a multienzyme system and may become a useful tool when used in biodegradation studies of xenobiotics, as well as indicate the physiological conditions of the basidiomycete fungus during the bioremediation process [10].

Considering that discoloration is not always an indication of successful detoxification, toxicity tests with the dye and with the textile effluent before and after discoloration were performed.

There was a variation in the germination rate $(\%)$ in the presence of the RBBR dye after treatment. In some treatments, this rate decreased, but in the majority, the germination rate remained the same as the control (96.67\%) (Table 1).

In the presence of the untreated and treated textile effluent a decrease of this rate was observed when compared to that of the control. When untreated and treated textile effluents were compared, no change in germination rate was observed (Table 2). 


\section{TABLE 1}

COMPARISON OF GERMINATION RATE (\%) AND ROOT LENGTH $(\mathrm{cm})$ OF L. SATIVA L., IN THE PRESENCE OF RBBR TEXTILE DYE

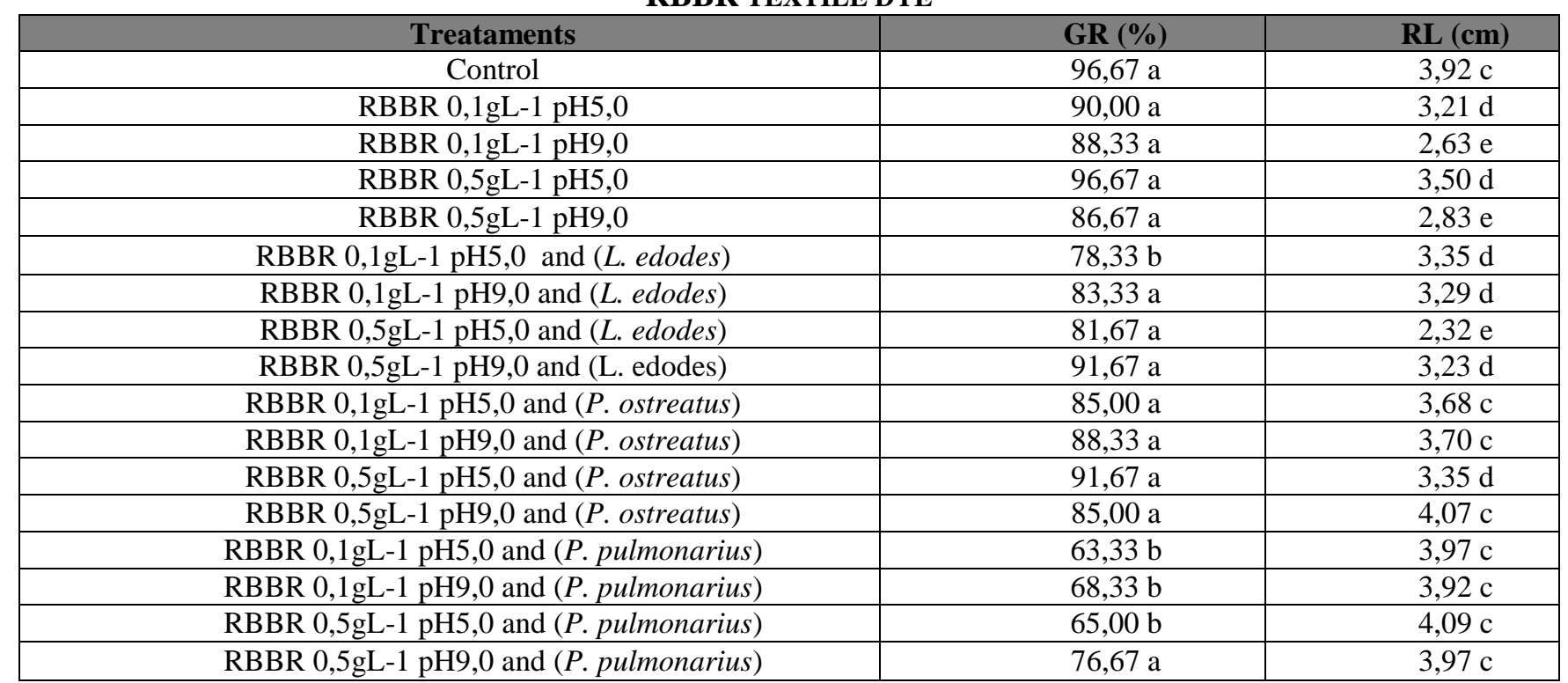

$C V($ germination rate $)=10,74 \% ; C V($ root length $)=8,07 \%$. Means followed by the same letter in the columns do not differ by Scott-Knott's test at 5\% significance.

TABLE 2

COMPARISON OF GERMINATION RATE (\%) AND ROOT LENGTH $(\mathrm{cm})$ OF L. SATIVA L. IN THE PRESENCE OF TEXTILE EFFLUENT

\begin{tabular}{|c|c|c|}
\hline Treatments & GR $(\%)$ & RL $(\mathbf{c m})$ \\
\hline Control & $96,67 \mathrm{a}$ & $3,92 \mathrm{c}$ \\
\hline Textile effluent not treated & $66,67 \mathrm{~b}$ & $5,05 \mathrm{a}$ \\
\hline Textile effluent and (L.edodes) & $75,00 \mathrm{~b}$ & $4,99 \mathrm{a}$ \\
\hline Textile effluent and(P. ostreatus) & $75,00 \mathrm{~b}$ & $4,46 \mathrm{~b}$ \\
\hline Textile effluent and (P. pulmonarius) & $73,33 \mathrm{~b}$ & $4,49 \mathrm{~b}$ \\
\hline
\end{tabular}

$C V($ germination rate $)=10.74 \% ; C V($ root length $)=8.07 \%$. Means followed by the same letter in the columns do not differ by Scott-Knott's test at 5\% significance

As shown in Table 1, in some treatments with the dye, after discoloration by fungi, there was a decrease in seed germination, which can be attributed to the production of intermediate metabolites more toxic than the original dye, which makes it necessary to perform of more studies [11].

When analyzed the growth of the root $(\mathrm{cm})$, this presented a great variation between the different treatments. In the presence of untreated dye, a decrease in root growth was observed when compared to control $(3.92 \mathrm{~cm})$ for all $\mathrm{pH}$ and concentration values (Table 1).

All treatments with the dye treated by the fungus Pleurotuspulmonarius showed an increase in root growth when compared to the untreated dye, demonstrating a decrease in toxicity to this parameter after treatment. In their studies with decolorization and detoxification of industrial reactive dyes [12], they found a significant reduction of toxicity after biological treatment.

In the treatments in the presence of untreated and treated textile effluent there was also a root growth promoter effect when compared to the control (Table 2).

There was also a relationship between lower germination rate and root length in treatments with the textile effluent (Table 2). This may have occurred because of the characteristic of plants competing for light, water and nutrients, revealing constant competition. This competition contributes to the survival of the species and, therefore, some have developed defense mechanisms, by which, during their growth, they release products of the secondary metabolism, thus preventing the germination and development of other plants relatively nearby, a process called allelopathy [13]. 
There are few ecotoxicological studies using dyes and industrial effluents before and after their treatment with fungi isolates, which is why the need for complementary studies to better understand this process (MALACHOVÁ et al., 2006 [14]).

\section{CONCLUSIONS}

The fungus Pleuriticpulmonarius was able to decolorize the RBBR dye, both at $\mathrm{pH} 5.0$ and at $\mathrm{pH} 9.0$ and at the two concentrations used, $0.1 \mathrm{gL}-1$ and $0.5 \mathrm{gL}-1$;

Lentinula edodes obtained better discoloration in the treatment with the RBBR dye at $\mathrm{pH} 5.0$ and 0.5 gL-1 and the fungus Pleurotusostreatus, in the treatments at $\mathrm{pH} 5.0$ and $0.5 \mathrm{gL}-1$ and at $\mathrm{pH} 9.0$ and $0.5 \mathrm{gL}-1$;

The dye showed a phytotoxic effect after the discoloration, reducing the germination rate in some treatments. However, after treatment with the fungus Pleurotuspulmonarius, it induced root growth, which did not present a toxic effect for this parameter;

The treatments with the textile effluent showed lower germination rates and, in contrast, higher promoter effect on root growth.

\section{ACKNOWLEDGEMENTS}

EPAMIG-Empresa de Pesquisa Agropecuária de Minas Gerais; FAPEMIG - Fundação de Amparo à Pesquisa de Minas Gerais; CNPq - Conselho Nacional de Desenvolvimento Científico e Tecnológico.

\section{REFERENCES}

[1] Pizato, E.; Lopes, A.C.; Rocha, R. D. C.; Barbosa, A.M and Cunha, M. A. A. Caracterização de efluente têxtil e avaliação da capacidade de remoção de cor utilizando o fungo LasiodiplodiatheobromaeMMPI. EngSanit Ambient, v.22, n.5, p. 1027-1035, 2017.

[2] Dasgupta, J.; Sikder J.; Chakraborty, S. ; Curcio, S. and Drioli, E. Remediation of textile effluents by membrane based treatment techniques: a state of the art review. J. Environ. Manag., n.147 , p. 55-72, 2015.

[3] Peixoto, F.; Marinho, G. and Rodrigues, K. Corantes têxteis: uma revisão. Holos, v. 5, 2013.

[4] Archna, L.K. and Siva, K.R.Biological methods of dye removal from textile effluents - a review. J. Biochem. Technol., n.3 ,p. 177180, 2012.

[5] Duarte, F.;Morais, V.; Maldonado-Hodar, F.J. and Madeira, L.M. Treatment of textile effluents by the heterogeneous Fenton process in a continuous packed-bed reactor using Fe/activated carbon as catalyst. Chem. Eng. J. n.232, p. 34-41, 2013.

[6] Kumaran, N.S. and Dharani, G. Decolorization of textile dyes by white rot fungi Phanerocheatechrysosporium and Pleurotussajorcaju. Journal of Applied Technology in Environmental Sanitation, v. 1, n. 4, p. 361-370, 2011.

[7] Kamida, H. M.; Durrant, L.R.; Monteiro, R.T.R. and Armas, E.D. Biodegradação de efluente têxtil por Pleurotussajor- caju. Química Nova, São Paulo, v. 28, n. 4, p. 629- 632, jul./ago. 2005.

[8] Palácio, S. M.; Nogueira, D. A.; Manenti, D. R.; Módenes, A. N.; Quiñones, F. R. E.; Borba, F. H. Estudo da toxicidade de efluente têxtil tratado por foto-fenton artificial utilizando as espécies Lactuca sativa e Artemia salina. Engevista, v. 14, n. 2, p. 127-134, 2012.

[9] Machado, K. M. G. and Matheus, D. R. Biodegradation of Remazol Brilliant Blue R by ligninolytic enzymatic complex produced by Pleurotusostreatus. Brazilian Journal of Microbiology, São Paulo, v. 37, n. 4, p. 468-473, July/Aug. 2006.

[10] Machado, K. M. G.; Matheus, D. R. and Bononi, V. L. Ligninolytic enzymes production and Remazol Brilliant Blue R decolorization by tropical Brazilian basidiomycetes fungi. Brazilian Journal of Microbiology, São Paulo, v. 36, n. 3, p. 246-252, May/June 2005.

[11] Somensi, C.A.; Simionatto, E.L.; Bertoli, S.L.; Wisniewski, A. and Radetski, C.M. Use of ozone in a pilot-scale plant for textile wastewater pre-treatment: physicochemical efficiency, degradation by-products identification and environmental toxicity of treated wastewater. J. Hazard. Mater. 175,p. 235-240, 2010.

[12] Casieri, L.; Varese, G.C.; Anastasi, A.; Prigioni, V.; Svobodobá, K.; FilippeloMarchisio, V.; and Novotiný, C. Decolorization and detoxication of reactive industrial dyes by immobilized fungi Trametespubescens and Pleurotusostreatus. Folia Microbiologica, Praha, v. 53, n. 1, p. 44-52, 2008.

[13] Alves, M. C. S.; Medeiros Filho, S.; Torres, S.B. Alelopatia de extratos voláteis na germinação de sementes e no comprimento da raiz de alface. Pesquisa Agropecuária Brasileira, Brasília, v. 39, n. 11, p. 1083-1086, 2004.

[14] Malachová, K.;Pavlícková, Z.; Novotný, C.; Svobodová, K.; Lednická D. Musílková, E.Reduction in the mutagenicity of synthetic dyes by successive treatment with activated sludge and the ligninolytic fungus, Irpexlacteus. Environmental and Molecular Mutagenesis, New York, v. 47, n. 7, p. 533-540, 2006. 